\title{
DINAMIKA BENTUK-BENTUK SAPAAN SEBAGAI REFLEKSI SIKAP BERBAHASA MASYARAKAT INDONESIA
}

\author{
Ridha Mashudi Wibowo * \\ Agustin Retnaningsih ${ }^{* *}$
}

\begin{abstract}
Greetings are one of the tangible proofs of human communications. One greets someone else because of the need to communicate. In this communication, the relationship between the two people communicating influences the choice of greeting forms. The selection of a greeting is assumed to be closely related to the language attitudes and perspectives of the speaker in positioning himself against the hearer. During its development, the use of greetings has shown a quite interesting dynamics. This comprises the development of greeting use, shift of greeting reference, and changes in the acts of greeting. This paper aims to describe the term of addressing used by the society, analiyzing manner and logic structure of the term of addressing, also the actualization and the dynamics of the usage of the term of addressing. Furthermore, to obtain varied data the author determines a population consisting of a number of groups, especially university students. This is with the assumption that in addition to their age level where they are highly productive in using greetings, it is also possible that they have ample forms of greetings and acts of greeting. Using speech act theory in sociolinguistics approach data was achieved with observation method in questioner and cards of data. The result of classification was analized with introspection, comparation, and equal-referential method which is formed in formal and informal description.From a number of semi-closed questionnaires listing questions about attitudes and selections of greeting the author obtains some results. These are a mapping of common greeting forms used by people in general, the background of common greeting forms used by people, and the actualization as well as dynamics of the use of greeting forms in Indonesian speech society.
\end{abstract}

Keyword: greeting, greeting forms, greeting form dynamics

\begin{abstract}
ABSTRAK
Sapaan merupakan salah satu bukti nyata komunikasi antarmanusia. Seseorang menyapa orang yang lain karena adanya kebutuhan untuk berkomunikasi. Dalam komunikasi tersebut, relasi antarkomunikan memengaruhi pemilihan bentuk sapaan. Pemilihan sapaan diasumsikan terkait erat dengan sikap berbahasa dan cara pandang penutur dalam memosisikan dirinya terhadap lawan tuturnya. Dalam perkembangannya, pemakaian sapaan memiliki dinamika yang cukup menarik. Dinamika tersebut meliputi perkembangan pemakaian sapaan, pergeseran pengacuan sapaan, dan perubahan penyapaan. Tulisan ini bertujuan untuk mendeskripsikan bentuk sapaan yang digunakan oleh masyarakat, menguraikan sikap dan struktur logika pemakaian bentuk sapaan, dan menguraikan aktualisasi dan dinamika pemakaian bentuk-bentuk sapaan dalam masyarakat. Selanjutnya, untuk memperoleh data yang variatif ditetapkan populasi data yang diperoleh dari sejumlah pembahan,
\end{abstract}

* Jurusan Sastra Indonesia, Fakultas Ilmu Budaya, Universitas Gadjah Mada

** Jurusan Sastra Indonesia, Fakultas Ilmu Budaya, Universitas Gadjah Mada 
khususnya mahasiswa, dengan asumsi bahwa selain mereka termasuk tingkat usia yang amat produktif dalam menggunakan sapaan, juga dimungkinkan mereka memiliki kekayaan bentuk sapaan dan atau penyapaan. Dengan menggunakan pendekatan sosiolinguistik mengenai tindak tutur, data diperoleh dengan metode simak dalam betuk kuesioner dan kartu data. Hasil klasifikasi data dianalisis dengan metode introspeksi, komparasi, dan padan referensial, serta disajikan dalam penyajian secara formal dan informal. Dari sejumlah kuesioner semitertutup yang berisi daftar tanyaan mengenai sikap dan pilihan sapaan yang mereka gunakan diperoleh hasil berupa pemetaan bentuk-bentuk sapaan yang umum digunakan oleh masyarakat, latar belakang pemakaian bentuk sapaan dalam masyarakat, serta aktualisasi dan dinamika penggunaan bentuk-bentuk sapaan dalam masyarakat bahasa Indonesia.

Kata kunci: bentuk-bentuk sapaan, dinamika bentuk sapaan, sapaan

\section{PENDAHULUAN}

Berbagai bentuk sapaan dipakai dalam banyak bentuk dan acuan. Mengikuti pandangan Sumampouw (2000:220) setiap tindak ujaran yang dihasilkan dalam peristiwa ujaran yang tercipta karena adanya interaksi sosial bersemuka dalam ragam apa pun melibatkan salah satu segi yang penting, yakni sistem penyapaan. Dalam interaksi sosial sistem sapaan mempunyai istilah lain, yaitu tutur sapa. Menurut Kridalaksana (1982:14) sistem tutur sapa merupakan "sistem yang mempertautkan seperangkat kata-kata atau ungkapan-ungkapan yang dipakai untuk menyebut dan memanggil para pelaku dalam suatu peristiwa bahasa". Para pelaku itu adalah pembicara $(\mathrm{O} 1)$, lawan bicara $(\mathrm{O} 2)$, dan yang disebutkan dalam pembicaraan (O3). Kata sapaan selain dapat mengawali suatu percakapan juga dapat melancarkan percakapan antara $\mathrm{O} 1$ dan O2. Selanjutnya, dalam Kridalaksana (1978:1415) disebutkan ada sembilan jenis kata sapaan dalam bahasa Indonesia, yaitu (1) kata ganti, (2) nama diri, (3) istilah kekerabatan, (4) gelar dan pangkat (title), (5) kata pelaku, (6) bentuk nominal, (7) kata-kata deiksis atau penunjuk, (8) nomina lain, (9) ciri zero atau nol. Penggunaan kata sapaan itu tergantung pada beberapa faktor, yaitu faktor kontak, jarak sosial, dan identitas pelaku. Selanjutnya, sapaan memegang peran penting karena dengan sapaan tersebut dapat ditentukan apakah suatu interaksi dapat berlanjut atau tidak. Walaupun sebagian besar pembicara tidak menyadari betapa pentingnya penggunaan sapaan, tetapi karena secara naluriah setiap pembicara akan berusaha berkomunikasi secara jelas dalam bahasa apa pun, sapaan hampir selalu digunakan (Subiyatningsih, 2008:73). Penggunaan sapaan dalam berkomunikasi tidak hanya dilihat dari cara penutur memanggil atau menyapa petuturnya, tetapi juga perlu diperhatikan respons petuturnya. Di dalam tulisan ini disajikan pembahasan sapaan pada ranah keluarga dengan melibatkan dua generasi di atas ego (penutur) dan satu generasi di bawah ego sejauh dimungkinkan. Dengan mengamati penyapaan antarpenutur itu dapat diketahui variasi penyapaan, kedekatan relasi antarpenutur, dan lebih jauh lagi refleksi sikap berbahasa masyarakatnya.

Terkait dengan uraian di atas, teori tindak tutur dalam sosiolinguistik menegaskan bahwa penutur atau partisipan memegang peran penting dalam aktivitas pertuturan. Dengan metode simak, data bentuk sapaan penutur diperoleh dalam 200 kuesioner dan kartu data. Penjaringan data kepada pembahan mahasiswa dilakukan pada Mei-Juni 2014 di kampus Fakultas Ilmu Budaya, Universitas Gadjah Mada, Yogyakarta pada sela-sela waktu kuliah. Pembahan mahasiswa dipilih karena mereka berasal dari berbagai daerah di Indonesia sehingga cakupan bentuk sapaan menjadi lebih luas. Setelah terklasifikasi, data sapaan dianalisis dengan metode introspeksi, komparasi, dan padan referensial. Hasil pengamatan yang disajikan secara formal dan informal itu menyatakan bahwa seiring dengan perkembangan zaman, bentuk-bentuk sapaan itu ada yang dianggap kedaluwarsa dan ada yang menjadi popular. Acuan dari pemakaian bentuk-bentuk sapaan juga sering kali mengalami pergeseran yang signifikan. Dengan memahami pemakaian bentuk-bentuk sapaan secara optimal, kesalahpahaman dalam interaksi antarpenutur dapat dihindarkan. Selain itu, dengan mengetahui variasi dan atau perkembangan bentuk-bentuk sapaan dapat berarti pula memahami perubahan bahasa beserta sebab-akibatnya. Dengan demikian, 
hal yang perlu ditunaikan terkait objek amatan itu sekurang-kurangnya ialah memetakan bentuk-bentuk sapaan yang umum digunakan oleh masyarakat, memaparkan latar belakang pemakaian bentuk sapaan dalam masyarakat, dan mengungkapkan aktualisasi dan dinamika bentukbentuk sapaan yang dipergunakan masyarakat Indonesia dewasa ini.

\section{BENTUK-BENTUK SAPAAN}

Sapaan ialah kata atau frasa untuk saling merujuk dalam pembicaraan dan dapat berbedabeda menurut sifat hubungan di antara pembicara itu, misalnya Anda, Ibu, dan Saudara (Sugono, 2014:1232). Sapaan terkait erat dengan nama dan sebutan. Nama yang dimaksud ialah kata untuk menyebut atau memanggil orang (Sugono, 2014:950). Adapun sebutan yang dimaksud ialah sesuatu yang disebut atau disebutkan; panggilan; nama; gelar (Sugono, 2014:1237). Dengan demikian, penelitian mengenai sapaan juga harus merujuk perihal nama dan sebutan.

Beberapa tulisan mengenai penamaan yang telah dipublikasikan antara lain sebagai berikut. Chaer (1995:43-52) menyatakan bahwa penamaan merupakan proses pelambangan suatu konsep untuk mengacu sesuatu referen yang berada di luar bahasa. Mengingat bahasa merupakan sesuatu yang arbitrer, antara satuan kebahasaan dan sesuatu yang dilambanginya tidak memiliki hubungan "wajib" sehingga pemberian nama pun dapat bersifat arbitrer. Wasiyati (2008:8) menyatakan bahwa penamaan merupakan sistem semantik dasar dari kata-kata. Nama memiliki dua karakter dasar, yakni fungsi referensial dan vokatif. Nama dapat digunakan untuk menarik perhatian atas kehadiran seseorang yang diberi lambang dengan nama itu atau untuk mengingatkan relevansi orang yang dinamai.

Uhlenbeck (1982) telah membahas ciri-ciri sistematis nama orang dalam bahasa Jawa. Di dalamnya secara garis besar dinyatakan bahwa penamaan dalam masyarakat Jawa dapat dikaitkan dengan jenis kelamin atau status sosial. Hal yang menarik disebutkan di dalamnya bahwa rupanya hampir tidak ada perumusan kaidah yang ketat dan jelas ihwal penamaan ini sehingga munculnya beberapa perkecualian harus diakui. Beberapa perkecualian itu dapat dijelaskan dengan memahami kebiasaan masyarakat Jawa dalam memilih nama, sedangkan beberapa perkecualian lain tidak. Sementara itu, Wibowo (2001) dalam "Nama Diri Etnik Jawa" membahas nama diri yang menjadi penanda identitas sekaligus sebagai simbol. Nama diri dapat dirunut asalnya dengan memperhatikan formulasi vokal yang dipakai dalam nama itu sebagai suatu kata; memperhatikan suku akhir komponen nama yang dapat menandai gender; dan memperhatikan jumlah silabe/suku kata pada nama itu. Selain nama itu ditetapkan secara arbitrer, sekadar untuk menandai identitas orang, nama juga dapat ditetapkan secara tertentu dengan tujuan, misalnya, memiliki tujuan, harapan, cita-cita, untuk menggambarkan aspek historisitas kelahiran, dan sebagainya.

Sementara itu, dalam Dinamika Tutur Sapa dalam Bahasa Indonesia (Kridalaksana, 1982), kata sapaan dalam bahasa Indonesia digolongkan menjadi sembilan jenis, yakni (1) kata ganti, seperti aku, kamu, dan ia; (2) nama diri, seperti Galih dan Ratna; (3) istilah kekerabatan, seperti bapak dan ibu; (4) gelar dan pangkat, seperti dokter dan guru; (5) bentuk pe + V(erbal) atau kata pelaku, seperti penonton dan pendengar; (6) bentuk $N$ (ominal) $+k u$, seperti kekasihku dan Tuhanku; (7) kata deiksis atau penunjuk, seperti sini dan situ; (8) kata benda lain, seperti tuan dan nyonya; serta (9) ciri zero atau nol, yakni adanya suatu makna tanpa disertai bentuk kata tersebut. Terkait sapaan ini Ngalimun (2012) dalam "Bentuk Sapaan Mesra Antaranggota Keluarga dalam Bahasa Jawa" mengungkapkan penggunaan sapaan di dalam keluarga, khususnya di dalam keluarga yang bersuku Jawa. Dari hasil penelitian disimpulkan bahwa interaksi antarindividu selalu melihat kedudukan seseorang dalam masyarakat. Selain itu, bentuk sapaan antaranggota keluarga dalam bahasa Jawa dapat dilihat dari kelengkapan unsur-unsurnya. Dalam tulisan ini, bentuk sapaan dilihat dari tiga aspek, yakni aspek morfologi, aspek sintaksis, dan aspek semantik. Dari aspek morfologi, bentuk sapaan dibagi menjadi tiga, yakni sapaan berupa bagian kata, sapaan berupa kata, dan sapaan berupa frase. Dari aspek sintaksis bentuk sapaan dibagi menjadi tiga, yakni sapaan yang terletak di depan klausa inti, sapaan yang terletak di belakang klausa inti, dan sapaan yang terletak di depan dan belakang klausa inti. Dari segi semantik, bentuk sapaan dapat berupa nama diri, istilah kekerabatan, paraban, gelar kebangsawanan, transposisi ajektif, dan poyokan 
(ejekan). Penelitian lain terkait sapaan yang ada di suatu daerah yaitu "Keragaman Sapaan dalam Tuturan Seputar Kegiatan Perdagangan di Pasar Banjaran, Kabupaten Bandung"(Saefullah, 2010). Dalam penelitian ini, Saefullah menganalisis dan mendeskripsikan ragam sapaan yang muncul di dalam respons petutur. Selain itu, penelitian ini mencari tahu faktor-faktor yang melatarbelakangi penggunaan sapaan tertentu di dalam respons. Dari penelitian ini ditemukan bahwa kata sapaan dalam kegiatan perdagangan di Pasar Banjaran bersifat asimetris walaupun antarpenutur sama-sama menggunakan istilah kekerabatan. Kemudian, faktor-faktor yang melatarbelakangi penggunaan sapaan adalah usia dan jenis kelamin. Adapun Sari (2013) meneliti bentuk dan pemakaian kata sapaan berdasarkan garis keturunan dan garis perkawinan di Kepenghuluan Bangko Kiri Kecamatan Bangko Pusako Kabupaten Rokan Hilir Provinsi Riau. Dalam "Sistem Kata Sapaan Kekerabatan dalam Bahasa Melayu di Kepenghuluan Bangko Kiri Kecamatan Bangko Pusako Kabupaten Rokan Hilir Provinsi Riau" disampaikan adanya temuan pola sapaan dalam bahasa Melayu di Kepenghuluan Bangko Kiri, Kecamatan Bangko Pusako, Kabupaten Rokan Hilir, Provinsi Riau yang didasarkan pada garis perkawinan. Pemakaian sapaan tersebut didasarkan pada perkawinan dan kekerabatan dengan ego.

Adapun Roselani (1991) dalam "Bentuk Sapaan dalam Bahasa Inggris dan Bahasa Indonesia" membahas pentingnya pemahaman konteks budaya dalam menggunakan bentuk sapaan dalam bahasa Inggris dan bahasa Indonesia secara tepat. Bahasa Indonesia memiliki jumlah pemakaian bentuk pronomina sapaan dan bentuk vokatif lebih variatif daripada bahasa Inggris bergantung dari strategi komunikasinya. Karena salah satu fungsi bahasa ialah memelihara hubungan sosial antarpenuturnya, kita perlu berhati-hati memakai bentuk sapaan secara tepat sesuai situasi, suasana, dan kedudukan kita terhadap orang yang kita sapa agar tidak menyinggung perasaannya.

Dibandingkan dengan tulisan-tulisan di atas, tulisan ini memiliki kekhasan, yakni (1) pembahan adalah mahasiswa yang rentang usianya 17-23 tahun, (2) pembahan rata-rata berasal dari kelas ekonomi menengah, (3) pembahan bukan hanya berasal dari satu daerah, melainkan dari berbagai daerah di Indonesia, (4) karena pembahan dari berbagai daerah, cakupan sapaan menjadi lebih luas, (5) adanya pemetaan variasi pola dan bentuk-bentuk sapaan yang digunakan secara nyata oleh pembahan, bukan hanya yang dikenal oleh etnik tertentu (mengingat adanya perkawinan antaretnik), dan (6) sapaan yang dimaksud mencakup juga nama dan sebutan.

\section{POLA DAN ACUAN BENTUK SAPAAN}

Berdasar data yang terkumpul dapat dilihat beberapa pola sapaan yang terdapat di dalamnya. Pola-pola sapaan tersebut dapat diklasifikasikan menjadi tiga bagian, yakni pola sapaan utuh, pola sapaan variasi utuh, dan pola sapaan sebagian. Pada pola sapaan utuh, sapaan dapat diklasifikasikan lagi menjadi lima, yakni pola sapaan berdasarkan bentuk sapaan, pola sapaan berdasarkan nama, pola sapaan berdasarkan julukan, pola sapaan berdasarkan paraban, dan pola sapaan berdasarkan panggilan. Berikut dapat diperhatikan bagan klasifikasi beserta uraiannya.

Bagan 1 Klasifikasi Pola Bentuk Sapaan

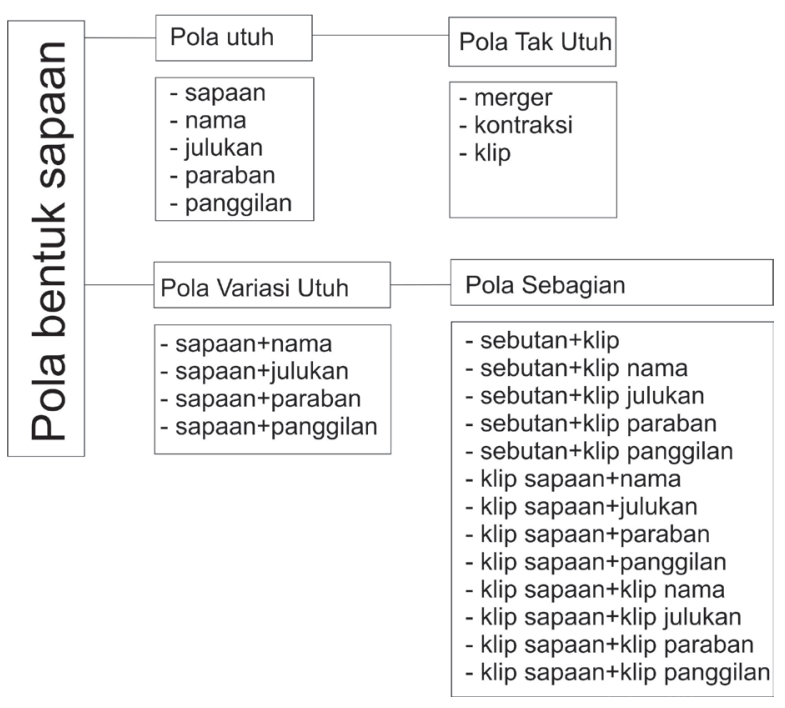

Sapaan utuh merupakan bentuk sapaan yang digunakan secara utuh oleh penyapa untuk menyapa, tanpa mengalami pemenggalan maupun penambahan dengan bentuk sapaan lain atau nama pesapa. Di bawah ini disajikan contoh-contoh penggunaan bentuk sapaan utuh yang digunakan oleh masyarakat Indonesia. 
Tabel 1

Bentuk-Bentuk Sapaan Pola Utuh

\begin{tabular}{|c|c|c|}
\hline No. & Sapaan & Referen \\
\hline 1. & Mamak & $\begin{array}{l}\text { kakak laki-laki ayah } \\
\text { orang tua perempuan ibu } \\
\text { ibu }\end{array}$ \\
\hline 2. & Aki & $\begin{array}{l}\text { kakak laki-laki ayah } \\
\text { adik laki-laki ayah }\end{array}$ \\
\hline 3. & Kakek & $\begin{array}{l}\text { orang tua laki-laki ayah } \\
\text { orang tua laki-laki ibu }\end{array}$ \\
\hline 4. & Nenek & $\begin{array}{l}\text { orang tua perempuan ibu } \\
\text { adik perempuan ibu }\end{array}$ \\
\hline 5. & Papa & ayah \\
\hline 6. & Mama & $\begin{array}{l}\text { ibu } \\
\text { adik perempuan ibu }\end{array}$ \\
\hline 7. & Bapak & $\begin{array}{l}\text { ayah } \\
\text { orang tua laki-laki ibu } \\
\text { kakak laki-laki ayah }\end{array}$ \\
\hline 8. & Ibu & $\begin{array}{l}\text { ibu } \\
\text { kakak perempuan ibu } \\
\text { adik perempuan ibu }\end{array}$ \\
\hline 9. & $\begin{array}{l}\text { Fikri } \\
\text { Yolan } \\
\text { Adri } \\
\text { Awal }\end{array}$ & $\begin{array}{l}\text { adik laki-laki } \\
\text { sepupu perempuan } \\
\text { kakak laki-laki } \\
\text { adik laki-laki }\end{array}$ \\
\hline 10. & $\begin{array}{l}\text { Si Cantik } \\
\text { Nyonya Menir } \\
\text { Permen } \\
\text { Bakwan }\end{array}$ & $\begin{array}{l}\text { keponakan perempuan } \\
\text { ibu } \\
\text { keponakan laki-laki } \\
\text { adik laki-laki }\end{array}$ \\
\hline 11. & $\begin{array}{l}\text { Gendut } \\
\text { Bencong } \\
\text { Jembluk }\end{array}$ & $\begin{array}{l}\text { sepupu laki-laki } \\
\text { adik laki-laki } \\
\text { adik perempuan }\end{array}$ \\
\hline 12. & $\begin{array}{l}\text { Dek } \\
\text { Mas } \\
\text { Genduk } \\
\text { Tole }\end{array}$ & $\begin{array}{l}\text { sepupu perempuan } \\
\text { sepupu laki-laki } \\
\text { keponakan perempuan } \\
\text { keponakan laki-laki }\end{array}$ \\
\hline
\end{tabular}

Dalam tabel di atas dapat dilihat data 1-8 adalah contoh bentuk sapaan, 9 adalah nama, 10 julukan, 11 paraban, dan 12 adalah panggilan yang referennya bisa berbeda.

Komponen sapaan yang berupa sapaan tak utuh dapat diklasifikasikan menjadi tiga, yaitu merger, kontraksi, dan klip. Disebut merger jika sapaan itu merupakan paduan dari komponen-komponen sapaannya, kontraksi jika ada penyingkatan pada komponen penyapaannya, dan klip jika dipakai potongan komponen sapaan dalam menyapa lawan tutur.
Tabel 2

Bentuk-Bentuk Sapaan Pola Tak Utuh

\begin{tabular}{|c|c|c|}
\hline No. & Sapaan & Referen \\
\hline 1. & Pak Ujang & adik laki-laki ayah \\
\hline 2. & Mbah Tri & $\begin{array}{l}\text { orang tua perempuan ayah } \\
\text { orang tua perempuan ibu }\end{array}$ \\
\hline 3. & Dek Dita & keponakan perempuan \\
\hline 4. & Aiy Alang & adik laki-laki ibu \\
\hline 5. & Pak Dhe & $\begin{array}{l}\text { kakak laki-laki ayah } \\
\text { kakak laki-laki ibu }\end{array}$ \\
\hline 6. & Bu Dhe & kakak perempuan ayah \\
\hline 7. & Pak Puh & $\begin{array}{l}\text { orang tua laki-laki ibu } \\
\text { kakak laki-laki ibu } \\
\text { kakak laki-laki ayah }\end{array}$ \\
\hline 8. & Yangti & $\begin{array}{l}\text { orang tua perempuan ayah } \\
\text { orang tua perempuan ibu }\end{array}$ \\
\hline 9. & $\mathrm{Ab}$ & anak \\
\hline 10. & Nang & kakak laki-laki \\
\hline 11. & Yak & adik perempuan \\
\hline 12. & Iik & adik perempuan \\
\hline 13. & Kak & $\begin{array}{l}\text { sepupu laki-laki } \\
\text { orang tua laki-laki ayah } \\
\text { orang tua laki-laki ibu }\end{array}$ \\
\hline 14. & Teh & $\begin{array}{l}\text { adik perempuan ayah } \\
\text { sepupu perempuan }\end{array}$ \\
\hline 15. & Idok & orang tua perempuan ibu \\
\hline 16. & Nyeng & adik laki-laki \\
\hline 17. & Pak Yan & kakak laki-laki ayah \\
\hline 18. & Buk Yan & kakak perempuan ayah \\
\hline
\end{tabular}

Data 1-4 pada tabel di atas menunjukkan pola sapaan yang terdiri atas gabungan (merger) antara bentuk sapaan dan nama. Penggunaan bentuk merger mencakup level paling bawah, yaitu level 1 atau garis anak sampai dengan level 4 atau garis kakek ego. Dalam hal ini, level 1 mengacu generasi anak ego, level 2 generasi ego, level 3 generasi orang tua ego, dan level 4 generasi orang tua dari orang tua ego. Penggunaan komponen sapaan berupa merger juga erat kaitannya dengan tujuan untuk membedakan dua atau lebih. Data 5-8 menunjukkan kontraksi atau pemendekan dari unsur bagian depan dan belakangnya, seperti Pak Dhe dari Bapak Gede, Bu Dhe (Ibu Gede), Pak Puh (Bapak Sepuh), Yangti (Eyang Putri). Selanjutnya, data 9-12 merupakan klip atau potongan nama, data 13-14 adalah klip kekerabatan, data 15-16 merupakan klip julukan, dan data 17-18 adalah klip sapaan pasangan marital.

Berikut ini diuraikan pola sapaan yang bervariasi dengan nama, julukan, paraban, dan panggilan. 
Tabel 3

Bentuk-Bentuk Sapaan Pola Variasi Utuh

\begin{tabular}{cll}
\hline No & \multicolumn{1}{c}{ Sapaan } & \multicolumn{1}{c}{ Referen } \\
\hline 1. & Mas Damar & sepupu laki-laki \\
2. & Mbak Lulu & sepupu perempuan \\
3. & Uni Azmi & sepupu perempuan \\
4. & Abah Asik & kakak laki-laki ibu \\
5. & Mas Cethol & sepupu laki-laki \\
6. & Bulek Cilik & adik ayah perempuan \\
7. & Mas Petho & sepupu laki-laki \\
8. & Lek Kentang & adik laki-laki ayah \\
9. & Om Gundul & adik ibu laki-laki \\
10. & Pakdhe Bagong & kakak ibu laki-laki \\
11. & Adek Gendut & adik laki-laki \\
12. & Mama Kakak & kakak perempuan ibu \\
13. & Si Bleh & sepupu laki-laki \\
14. & Om Beng-beng & adik laki-laki ayah \\
15. & Onang Queen & sepupu perempuan \\
\hline
\end{tabular}

Pada tabel di atas data 1-4 adalah pola sapaan variatif dengan nama, 5-8 pola variasi dengan julukan, 9-12 pola variasi dengan paraban, dan data 13-15 adalah pola variasi dengan panggilan.

Selanjutnya, berikut ini dijelaskan penyebutan dengan pola sebagian dimulai dari kelompok data pola sebutan + klip.

Tabel 4

Bentuk Sapaan Pola Sebutan + Klip

\begin{tabular}{cll}
\hline No. & \multicolumn{1}{c}{ Sapaan } & \multicolumn{1}{c}{ Referen } \\
\hline 1 & Mas Lev & sepupu laki-laki \\
2 & Om Rus & adik laki-laki ibu \\
3 & Mbak Lis & sepupu perempuan \\
4 & Mas Auf & sepupu laki-laki \\
5 & Mas Kim & sepupu laki-laki \\
\hline
\end{tabular}

Selain data pada tabel di atas, ada pula bentuk sapaan yang diikuti dengan klip nama sebagaimana yang disajikan dalam tabel itu. Penggunaannya pun bermacam-macam. Ada yang digunakan untuk memanggil sepupu laki-laki ego, seperti Mas Lev, Mas Auf, dan Mas Kim. Ada pula yang digunakan untuk menyapa sepupu perempuan, seperti Mbak Lis. Selain digunakan untuk menyapa kerabat pada level 2, pola sapaan ini juga digunakan untuk menyapa anggota kerabat pada level 3, misalnya untuk menyapa adik laki-laki ibu (Om Rus).
Data berpola sapaan + klip dapat dilihat pada uraian berikut.

Tabel 5

Bentuk Sapaan Berpola Sapaan + Klip

\begin{tabular}{cll}
\hline No. & \multicolumn{1}{c}{ Sapaan } & \multicolumn{1}{c}{ Referensi } \\
\hline 1 & Mama Ref & kakak ibu perempuan \\
2 & Om Zam & adik ibu laki-laki \\
3 & Tante Din & adik ayah perempuan \\
4 & Pakde No & kakak ibu laki-laki \\
5 & Om Pin & adik laki-laki ibu \\
6 & Paklek Ndut & kakak laki-laki ayah/ibu \\
7 & Pak Tengah & kakak ayah laki-laki \\
8 & Si Bleh & sepupu laki-laki \\
9 & Mbak Ayik & sepupu perempuan \\
10 & Uda Idin & adik ayah laki-laki \\
\hline
\end{tabular}

Dalam tabel di atas terlihat data 1-4 adalah sapaan berpola sapaan + klip nama. Pola sapaan yang diikuti dengan klip julukan, misalnya $\mathrm{Om}$ Pin (data 5). Pin berasal dari julukan Pipin (Arifin) yang diberikan ibunya semasa kecil dan terbawa hingga besar sehingga keponakan-keponakannya pun memanggilnya dengan $\mathrm{Om}$ Pin. Data 6-7 merupakan pola sapaan yang diikuti klip paraban, yakni Paklek Ndut. Ndut merupakan potongan dari kata gendut. Paklek Ndut dapat digunakan untuk menyapa kakak laki-laki ayah atau kakak laki-laki ibu. Pak Tengah adalah sebutan kepada kakak ayah laki-laki yang merupakan saudara kedua dari 3 bersaudara. Data 8 adalah sapaan + klip julukan yang ditandai dengan si. Adapun data 9-10 adalah bentuk sapaan + panggilan.

Bentuk data sapaan berpola klip sapaan + unsur lain disebutkan di bawah ini.

Tabel 6

Bentuk Sapaan Berpola Klip Sapaan + Unsur Lain

\begin{tabular}{cll}
\hline No. & \multicolumn{1}{c}{ Sapaan } & \multicolumn{1}{c}{ Referen } \\
\hline 1 & Mak Upik & kakak perempuan ibu \\
2 & Bang Edo & kakak laki-laki \\
3 & Dek Nouva & keponakan perempuan \\
4 & Lek Kecil & adik laki-laki/perempuan ayah /ibu \\
5 & Lek Ganteng & adik laki-laki ayah \\
6 & De Puput & kakak perempuan ayah atau ibu. \\
\hline
\end{tabular}


Ada beberapa contoh penggunaan bentuk klip sapaan yang diikuti dengan nama, misalnya Mak Upik yang digunakan untuk menyapa kakak perempuan ibu. Tidak hanya untuk menyapa kakak perempuan ibu, bentuk klip sapaan yang diikuti dengan nama lazim juga digunakan untuk menyapa kakak laki-laki ego, kakak perempuan ego, keponakan perempuan ego, adik perempuan ayah ego, dan adik laki-laki ayah ego. Untuk menyapa kakak laki-laki ego digunakan Bang Edo. Ego menggunakan Dek Nouva untuk menyapa keponakan perempuannya. Klip sapaan yang diikuti dengan julukan tidak ditemukan datanya dalam kuesioner. Padahal, sapaan jenis ini juga lazim ditemukan di Indonesia. Hanya saja, frekuensi pemakaiannya tidak setinggi pola-pola sapaan yang lain. Contoh klip sapaan yang diikuti dengan julukan misalnya Lek Kecil. Lek Kecil bisa digunakan untuk menyapa adik laki-laki atau adik perempuan ayah atau ibu. Julukan kecil barangkali bisa diberikan karena ia lahir hampir bersamaan dengan lahirnya anak kakaknya sehingga ia dipanggil Lek Kecil oleh keponakan-keponakannya. Selanjutnya, contoh penggunaan klip sapaan yang diikuti paraban adalah Lek Ganteng. Lek Ganteng adalah bentuk yang digunakan ego untuk menyapa adik laki-laki ayah. Dalam rangka membedakan kedua adik laki-laki ayah, ego mengimbuhkan paraban setelah bentuk sapaan Lek agar memudahkan pengidentifikasian adik laki-laki ayah yang mana yang diajak berbicara atau disapa. Adapun pola sapaan berupa klip sapaan yang diikuti dengan panggilan tidak ditemukan dalam kartu data. Akan tetapi, pembahasan mengenai klip sapaan yang diikuti panggilan perlu disinggung dalam tulisan ini karena ditemukan pola sapaan yang demikian ini di dalam masyarakat. Contoh klip sapaan yang diikuti dengan panggilan misalnya De Puput. De merupakan klip yang berasal dari kata Bude yang lazim digunakan oleh masyarakat Indonesia, khususnya, Jawa untuk menyapa kakak perempuan ayah atau ibu.

Dalam pada itu, data sapaan berpola klip sapaan + klip dapat diperhatikan dalam tabel berikut.

Tabel 7

Bentuk Sapaan Berpola Klip + Klip

\begin{tabular}{|c|c|c|}
\hline No. & Sapaan & Referen \\
\hline 1. & Ka' Ozy & sepupu laki-laki \\
\hline 2. & Dek Ki & adik perempuan \\
\hline
\end{tabular}

\begin{tabular}{cll}
\hline No. & \multicolumn{1}{c}{ Sapaan } & \multicolumn{1}{c}{ Referen } \\
\hline 3. & Lek Ti & adik perempuan ayah \\
4. & Boyem & orang tua perempuan ibu \\
\hline
\end{tabular}

Pola klip sapaan diikuti dengan klip nama sebagaimana yang disajikan dalam tabel di atas kiranya banyak dipakai dan bentuk ini digunakan hampir di setiap tingkat kekerabatan. $K a^{\prime} O z y$ dan Dek $K i$, misalnya, digunakan untuk memanggil kerabat pada level 2, yaitu kepada sepupu lakilaki dan kepada adik perempuan ego. Pada level 3 , pola sapaan berupa klip sapaan diikuti dengan klip nama, misalnya Lek Ti yang digunakan untuk menyapa adik perempuan ayah oleh ego. Boyem merupakan contoh penggunaan pola klip sapaan yang diikuti dengan klip nama. Boyem digunakan oleh ego untuk memanggil nenek dari ibunya.

Bentuk klip sapaan yang diikuti dengan klip julukan juga ditemukan dalam masyarakat Indonesia, tetapi pola ini tidak dapat ditemukan di kartu data. Lek Mo, misalnya, merupakan salah satu contoh penggunaan klip sapaan yang diikuti dengan klip julukan. Lek dapat berasal dari kata Bulek atau Paklek yang lazim digunakan oleh masyarakat Indonesia untuk menyapa kakak perempuan atau laki-laki dari ayah atau ibunya. Mo berasal dari kata limo, misalnya, yang dalam bahasa Jawa berarti 'lima'. Lek Mo bisa jadi merupakan bentuk sapaan yang digunakan ego untuk memanggil adik kelima ayahnya atau anak kelima dalam keluarga ayahnya.

Sementara itu, bentuk klip sapaan + klip panggilan dapat dilihat berikut ini.

Tabel 8

Bentuk Klip Sapaan dan Klip Panggilan

\begin{tabular}{|c|c|c|}
\hline No. & Sapaan & Referen \\
\hline 1 & Bi Iya & adik perempuan ibu \\
\hline 2 & Bi Not & adik perempuan ibu \\
\hline
\end{tabular}

Pola sapaan yang terdiri atas klip sapaan yang diikuti klip panggilan juga digunakan oleh masyarakat Indonesia untuk menyapa kerabatnya. Bentuk itu misalnya Bi Iya dan Bi Not. Baik Bi Iya maupun Bi Not digunakan oleh ego untuk memanggil adik perempuan ibu. 


\section{LATAR BELAKANG PEMILIHAN BENTUK SAPAAN}

Pemakaian bentuk sapaan didasarkan atas pertimbangan tertentu. Orang tidak bisa seenaknya menggunakan bentuk sapaan kepada lawan tuturnya disebabkan dampak komunikasi yang timbul dapat berupa ketidaknyamanan secara psikologis, etis, dan sosial. Berdasarkan hasil pengamatan latar belakang, pemilihan sapaan memiliki beberapa variabel, yaitu urutan, usia, kelahiran, gender, kedekatan relasi, lokasi, profesi, agama, tren, lapisan masyarakat, dan pewarisan. Secara berturut-turut variabel-variabel itu diuraikan berikut ini.

Urutan merupakan hal dominan yang melatarbelakangi pemilihan pemakaian bentuk sapaan. Urutan yang dimaksud berupa urutan usia dan urutan kelahiran. Berikut paparan selengkapnya.

Tabel 9

\begin{tabular}{cll}
\multicolumn{3}{c}{ Bentuk Sapaan Berdasarkan Usia } \\
\hline No. & \multicolumn{1}{c}{ Sapaan } & \multicolumn{1}{c}{ Referen } \\
\hline 1. & Ka' Ozy & sepupu laki-laki \\
2. & Dek Ki & adik perempuan \\
3. & Bang Edo & kakak laki-laki \\
4. & Dek Nouva & keponakan perempuan \\
\hline
\end{tabular}

Dari data di atas dapat diketahui bahwa sapaan di Indonesia merefleksikan urutan usia penuturnya. Usia $K a^{\prime} O z y$ dan Bang Edo lebih tua daripada ego. Oleh sebab itu, ego menggunakan sapaan $\mathrm{Ka}$ ' dan Bang yang diimbuhkan sebelum nama pesapa. Sementara itu, usia Dek Ki dan Dek Nouva lebih muda daripada ego. Hal itu menyebabkan ego mengimbuhkan sapaan Dek di depan nama atau klip nama pesapa.

Urutan dapat pula diartikan sebagai urutan kelahiran. Berikut disajikan contohnya.

Tabel 10

Bentuk Sapaan Berdasarkan Kelahiran

\begin{tabular}{cll}
\hline No. & \multicolumn{1}{c}{ Sapaan } & \multicolumn{1}{c}{ Referen } \\
\hline 1 & Eda Tua & sepupu perempuan \\
2 & Eda Tengah & sepupu perempuan \\
3 & Pak Tangah & adik laki-laki ayah \\
4 & Bibi Tua & adik perempuan ayah \\
5 & Bibi Tengah & adik perempuan ayah \\
6 & Bibi Uda & adik perempuan ayah \\
7 & Inang Tangah & kakak perempuan ayah \\
\hline
\end{tabular}

Pemilihan sapaan yang digunakan dapat didasarkan pada urutan kelahiran kerabat ego. Seperti yang terteta dalam tabel, ego menambahkan kata yang menunjukkan urutan kelahiran setelah bentuk sapaan yang digunakan, misalnya Tua untuk 'tertua' atau Tengah untuk 'tengah' atau 'yang kedua'. Eda Tua dan Eda Tengah digunakan untuk menyapa sepupu perempuan ego. Bibi Tua, Bibi Tengah, dan Bibi Uda digunakan oleh ego untuk menyapa adik perempuan ayah ego. Pak Tangah dan Inang Tangah, berturut-turut, digunakan untuk menyapa kakak laki-laki ayah dan kakak perempuan ayah.

Pemakaian bentuk sapaan dapat pula dipertimbangkan berdasarkan gender seperti terlihat dalam tabel berikut.

Tabel 11

Bentuk Sapaan Berdasarkan Gender

\begin{tabular}{cll}
\hline No. & \multicolumn{1}{c}{ Sapaan } & \multicolumn{1}{c}{ Referen } \\
\hline 1 & Eyang Kakung & orang tua laki-laki ibu \\
2 & Eyang Putri & orang tua perempuan ibu \\
\hline
\end{tabular}

Sapaan, khususnya kepada kerabat, di Indonesia juga dapat merefleksikan gender. Dari tabel di atas, diketahui ada pembeda gender dalam sapaan di Indonesia. Bentuk pembeda gender tersebut disertakan setelah bentuk sapaan Eyang. Eyang yang diikuti dengan kata kakung memiliki referen orang tua laki-laki ayah atau ibu ego. Eyang yang diikuti kata putri memiliki referen orang tua perempuan ayah atau ibu. Bentuk sapaan yang merefleksikan gender, tidak sepenuhnya terdapat secara eksplisit di dalam sebuah sapaan. Ada pula yang direfleksikan secara implisit dalam sapaan seperti kata Mas dan Mbak. Mas merefleksikan gender pesapa laki-laki meskipun tidak secara eksplisit diikuti bentuk lanang atau kakung yang dalam bahasa Jawa berarti laki-laki. Begitu pun mbak yang secara implisit merefleksikan gender pesapa perempuan, meskipun tidak diikuti kata putri setelahnya.

Berdasarkan kedekatan relasi antarpenutur, contoh bentuk sapaan dapat diperlihatkan berikut ini. 
Tabel 13

Bentuk Sapaan Berdasarkan Kedekatan Relasi

\begin{tabular}{|c|c|c|}
\hline No. & Sapaan & Referen \\
\hline 1 & Bos & ayah \\
\hline 2 & Bakwan & adik laki-laki \\
\hline
\end{tabular}

Tabel di atas menunjukkan bahwa bentuk bos digunakan untuk menyapa ayah ego. Jika tidak ada kedekatan relasi antara ego dan ayahnya, sudah tentu ego tidak berani memanggil ayahnya dengan Bos. Ego menggunakan bentuk bos juga karena ada ketergantungan secara finansial kepada pesapa, yaitu ayah dan ibunya sehingga ia menggunakan Bos untuk menyapa ayah dan ibunya. Bentuk bakwan digunakan ego untuk menyapa adik laki-lakinya. Karena ada kedekatan relasi, ego memanggil adiknya dengan sebutan Bakwan. Meskipun dipanggil Bakwan, bukan berarti adik laki-laki ego menyukai bakwan. Ego memanggil adik laki-lakinya Bakwan karena ada kesamaan suku akhir nama adik laki-lakinya, Wawan, dan bakwan sehingga ego memanggil adik laki-lakinya demikian.

Berdasarkan lokasi antarpenutur berikut ini disajikan contoh bentuk sapaannya.

Tabel 14

Bentuk Sapaan Berdasarkan Lokasi

\begin{tabular}{clc}
\hline No. & \multicolumn{1}{c}{ Sapaan } & \multicolumn{1}{c}{ Referen } \\
\hline 1 & Mbah Banyumas & orang tua perempuan ayah \\
2 & Ama & orang tua laki-laki ibu \\
3 & Eyang Kakung & orang tua laki-laki ibu \\
\hline
\end{tabular}

Untuk membedakan antara kerabat satu dengan kerabat yang lain, diperlukan penanda atau pembeda dalam menyapa kerabat tersebut. Berdasarkan data di atas, lokasi juga dapat menjadi dasar dalam pemilihan bentuk sapaan. Karena pembahan memiliki dua nenek, maka untuk membedakannya pembahan memilih menggunakan Mbah Banyumas untuk menyapa nenek dari ibunya. Sapaan yang merefleksikan lokasi juga tidak semuanya secara eksplisit menunjukkan lokasi penuturnya seperti pada data Mbah Banyumas. Akan tetapi, tidak semua data secara eksplisit menunjukkan lokasi penuturnya, ada data yang secara implisit merefleksikan lokasi penuturnya. Ama dan Eyang Kakung, misalnya, secara implisit menunjukkan lokasi penuturnya.
Ama merefleksikan penuturnya berasal dari daerah di luar Jawa, yaitu dari daerah Nusa Tenggara Timur dan Eyang Kakung merefleksikan lokasi penuturnya dari Jawa, yaitu dari Jawa Tengah.

Profesi penutur dapat pula menjadi pertimbangan dalam memilih bentuk sapaan yang tepat. Berikut disajikan contohnya.

Tabel 15

Bentuk Sapaan Profesi

\begin{tabular}{ccc}
\hline No. & Sapaan & Referen \\
\hline 1. & Om Trasi & Adik laki-laki ayah \\
\hline
\end{tabular}

Om Trasi, misalnya, digunakan oleh ego untuk menyapa adik laki-laki dari ayah. Pemanggilan tersebut bisa saja terjadi karena adik laki-laki dari ayahnya tersebut bekerja di pabrik terasi atau menjadi penjual terasi. Selain Om Trasi, masih ada bentuk sapaan lain yang merefleksikan profesi pesapa. Akan tetapi, dalam kartu data hanya terekam satu bentuk profesi yang direfleksikan melalui bentuk sapaan. Bentuk sapaan lain yang merefleksikan profesi misalnya Pakde Yai, Paklek Becak, atau Bulik Bakmi. Pakde Yai merefleksikan profesi kakak laki-laki orang tua ego sebagai kyai atau orang yang memiliki ilmu spiritual. Paklek Becak merefleksikan profesi adik laki-laki orang tua ego berprofesi tukang becak dan Bulik Bakmi merefleksikan profesi adik perempuan orang tua ego sebagai penjual bakmi.

Selanjutnya, berdasarkan agama dapat diperoleh data sapaan berikut ini.

Tabel 16

Bentuk Sapaan Berdasarkan Agama

\begin{tabular}{|c|c|c|}
\hline No. & Sapaan & Referen \\
\hline 1 & Abah & $\begin{array}{l}\text { ayah } \\
\text { orang tua laki-laki Ibu }\end{array}$ \\
\hline 2 & Umi & $\begin{array}{l}\text { ibu } \\
\text { orang tua perempuan Ayah }\end{array}$ \\
\hline
\end{tabular}

BentukUmi dan Abah digunakan oleh ego yang berlatar belakang agama Islam dan orang tuanya beragama sama. Bentuk Umi dan Abah di Indonesia tidak hanya digunakan untuk menyapa ayah dan ibu, tetapi juga untuk menyapa kakek dan nenek ego.

Berdasarkan tren pergaulan diperoleh data sapaan sebagai berikut. 
Tabel 17

Bentuk Sapaan Berdasarkan Tren

\begin{tabular}{cll}
\hline No. & Sapaan & \multicolumn{1}{c}{ Referen } \\
\hline 1 & Cuy & sepupu laki-laki \\
2 & Ndunk & kakak laki-laki \\
3 & Cuk & sepupu laki-laki \\
4 & Bro & saudara atau yang dianggap saudara \\
& & laki-laki \\
\hline
\end{tabular}

Sapaan yang sedang tren dapat digunakan sebagai dasar dalam pemilihan sapaan yang digunakan untuk kerabat, misalnya Cuy, Ndunk, Cuk, dan Bro. Cuy dan Cuk digunakan untuk menyapa sepupu laki-laki ego. Ndunk digunakan untuk menyapa kakak laki-laki ego. Bentuk Bro, selain digunakan dalam penyapaan kepada kerabat, juga digunakan untuk menyapa teman sebagaimana yang terjadi dalam masyarakat. Dalam sosial media, ditemukan banyak sapaan yang variatif, seperti Sis, Gan, Cin, Say, dan lain sebagainya. Penggunaan sapaan yang sedang tren di kalangan teman bersifat sangat personal. Maksudnya, fungsi penggunaan sapaan yang sedang tren antara satu orang dengan orang yang lain berbeda-beda. Ada yang menggunakannya dengan teman sebaya, teman dekat, atau teman di media sosial

Lapisan masyarakat rupanya secara signifikan memperlihatkan pemakaian sapaan secara berbeda. Berikut disajikan contohnya.

Tabel 18

Bentuk Sapaan Berdasarkan Lapisan Masyarakat

\begin{tabular}{clll}
\hline No. & \multicolumn{2}{c}{ Sapaan } & Referen \\
\hline 1 & Papa & ayah & \\
2 & Mama & ibu & \\
3 & Pak & ayah & \\
4 & Mbok & ibu & \\
\hline
\end{tabular}

Sapaan tersebut merefleksikan lapisan masyarakat tempat ego tinggal. Penggunaan Mama dan Papa merefleksikan lapisan masyarakat ego yang berada di kelas menengah ke atas, sedangkan Pak dan Mbok merefleksikan lapisan masyarakat ego yang berada di kelas menengah ke bawah. Meskipun ditunjukkan secara implisit, lapisan masyarakat juga ternyata dapat direfleksikan melalui bentuk sapaan yang digunakan.

Terkait pewarisan kepada generasi selanjutnya, berikut ini diperlihatkan data yang dimungkinkan menjadi evidensi atas fakta itu.

Tabel 19

Bentuk Sapaan Berdasarkan Pewarisan

\begin{tabular}{clll}
\hline No. & \multicolumn{2}{c}{ Sapaan } & Referen \\
\hline 1 & Papa & ayah & \\
2 & Mama & ibu & \\
3 & Opa & ayah & \\
4 & Oma & ibu & \\
\hline
\end{tabular}

Tabel tersebut menunjukkan bahwa ada pewarisan dalam bentuk sapaan yang digunakan oleh masyarakat Indonesia, baik itu pewarisan yang diakibatkan oleh kolonialisme atau dari etnis pendatang di Indonesia. Bentuk Papa dan Mama merupakan bentuk yang didapat dari kolonialisme Eropa di Indonesia, sedangkan bentuk Opa dan Oma adalah bentuk yang diperoleh dari adanya kontak dari etnis Cina yang datang dan tinggal di Indonesia.

\section{DINAMIKA BENTUK-BENTUK SAPAAN}

Berdasarkan data yang diperoleh dapat dilihat berbagai bentuk sapaan yang menggambarkan perubahan pemakaian bentuk sapaan. Perubahan bentuk ini dapat diamati dari sapaan yang digunakan ego untuk memanggil anggota keluarganya berdasarkan level atau tingkat kekerabatannya. Tingkat kekerabatan ini dibagi menjadi empat, yakni tingkat kekerabatan keempat, tingkat kekerabatan ketiga, tingkat kekerabatan kedua, dan tingkat kekerabatan pertama. Tingkat kekerabatan keempat meliputi garis orang tua ayah dan garis orang tua ibu. Tingkat kekerabatan ketiga meliputi garis orang tua ego. Tingkat kekerabatan kedua meliputi garis ego. Tingkat kekerabatan pertama meliputi garis anak ego.

Perlu dicatat bahwa data yang digunakan datang dari pembahan yang berasal dari pulau Jawa yang mayoritas berasal dari Jawa Timur, Jawa Tengah, Yogyakarta, Jawa Barat, dan DKI Jakarta. Untuk melihat perubahan-perubahan yang terjadi, berikut disajikan uraian mengenai macam-macam bentuk sapaan berdasarkan tingkat kekerabatannya.

Orang tua ayah dan orang tua ibu ego merupakan tingkat kekerabatan tertinggi yang 
diketahui atau dikenal oleh ego. Hal ini disebabkan oleh rentang usia antara keduanya yang cukup terpaut jauh. Dalam tingkatan ini pun setidaknya terbagi menjadi dua, yakni orang tua laki-laki ayah atau ibu dan orang tua perempuan ayah atau ibu. Persentase pemakaian bentuk-bentuk sapaan pada tingkatan ini dapat dilihat pada diagram berikut.
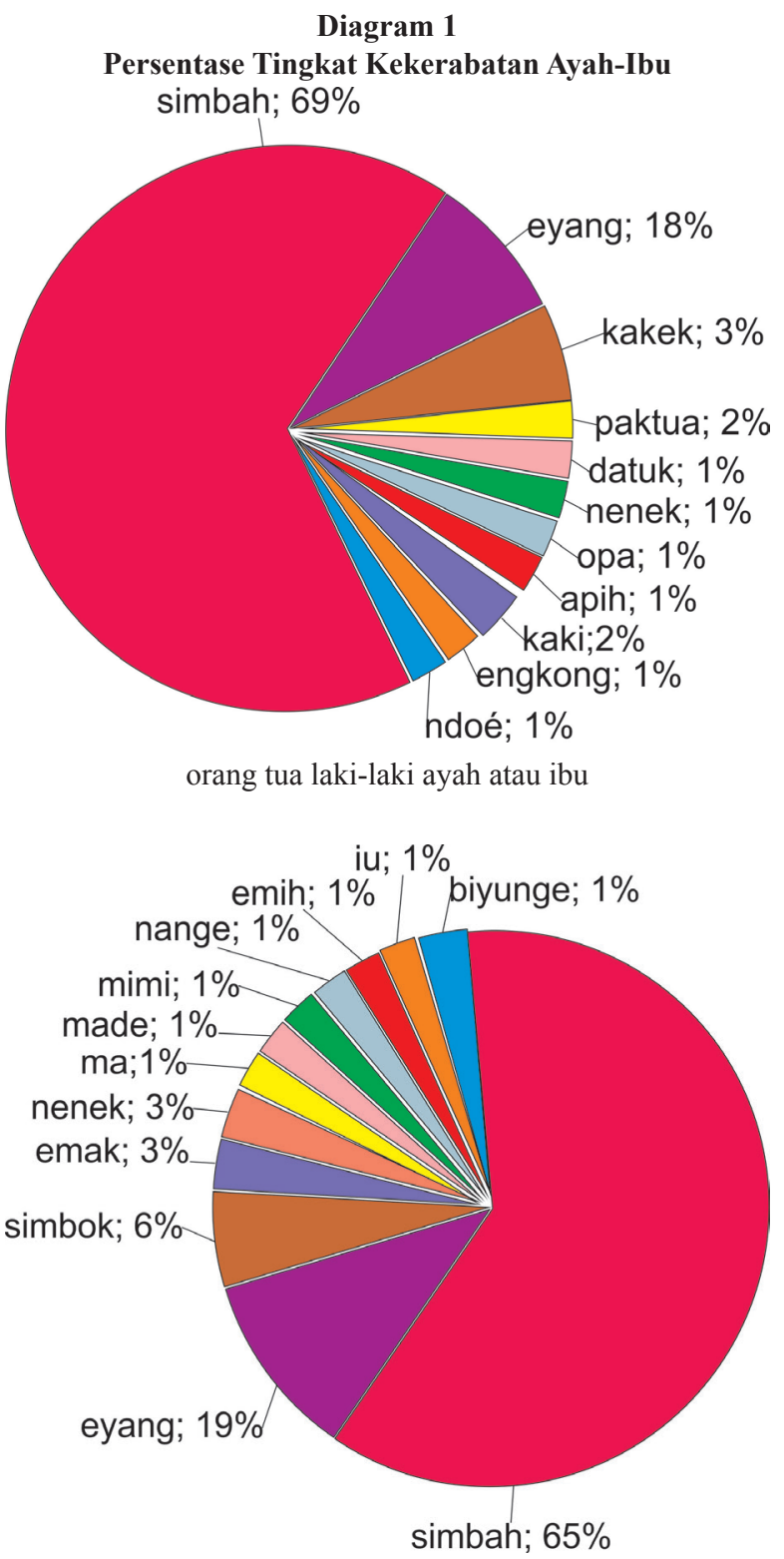

orang tua perempuan ayah atau ibu

Pada diagram orang tua laki-laki ayah atau ibu didapat persentase bentuk sapaan yang didominasi oleh sapaan simbah sebanyak 69\% dan eyang sebanyak $18 \%$. Selain itu, muncul sapaan-sapaan berbentuk lain yang sangat bervariasi, seperti datuk, paktua, engkong, kakek, nenek, dan sebagainya. Penggunaan sapaan simbah dan eyang yang cukup mendominasi tersebut dipengaruhi oleh tingkat penggunaan bahasa Jawa di pulau Jawa yang cukup tinggi. Bentuk sapaan simbah dan eyang merupakan bentuk sapaan yang digunakan masyarakat Jawa untuk menyebut orang tua lakilaki ayah atau ibu. Kemudian, penggunaan variasivariasi bentuk sapaan seperti datuk, apih, engkong, paktua, dan sebagainya dapat disebabkan oleh pernikahan beda suku yang dilakukan oleh orang tua ego dan juga pemakaian bahasa etnis masingmasing orang tua.

Tidak jauh berbeda dengan sapaan terhadap orang tua laki-laki ayah dan ibu ego, sapaan terhadap orang tua perempuan ayah dan ibu ego pun memiliki pola yang hampir sama. Pada diagram di atas digambarkan bahwa bentuk sapaan simbah dan eyang mendominasi. Akan tetapi, dalam pemakaiannya, biasanya ego akan memberi sapaan tambahan untuk membedakan jenis kelamin di antara keduanya, seperti simbah putri, eyang kakung, dan sebagainya. Bentuk sapaan lain yang berbau etnis lain pun bermunculan, seperti penggunaan sapaan emih, simbok, emak, dan sebagainya. Dari sini dapat dilihat bahwa penggunaan bentuk sapaan di pulau Jawa terhadap orang tua laki-laki dan orang tua perempuan ayah dan ibu ego masih sangat kental unsur kedaerahannya. Meskipun sebagian besar penduduk di pulau Jawa sudah fasih berbahasa Indonesia, mereka masih memilih untuk menggunakan sapaan dengan unsur kedaerahan yang cukup kental.

Tingkat kekerabatan berikutnya adalah tingkat kekerabatan pada garis orang tua ego. Tingkatan ini meliputi ayah, ibu, kakak laki-laki ayah atau ibu, kakak perempuan ayah atau ibu, adik laki-laki ayah atau ibu, dan adik perempuan ayah atau ibu. Tingkatan ini merupakan tingkatan yang kekerabatannya berada tepat di atas ego. Pemakaian bentuk sapaan di dalam tingkatan ini disajikan dalam beberapa diagram. Diagram di bawah ini merupakan diagram bentuk-bentuk sapaan terhadap ayah dan ibu ego. 

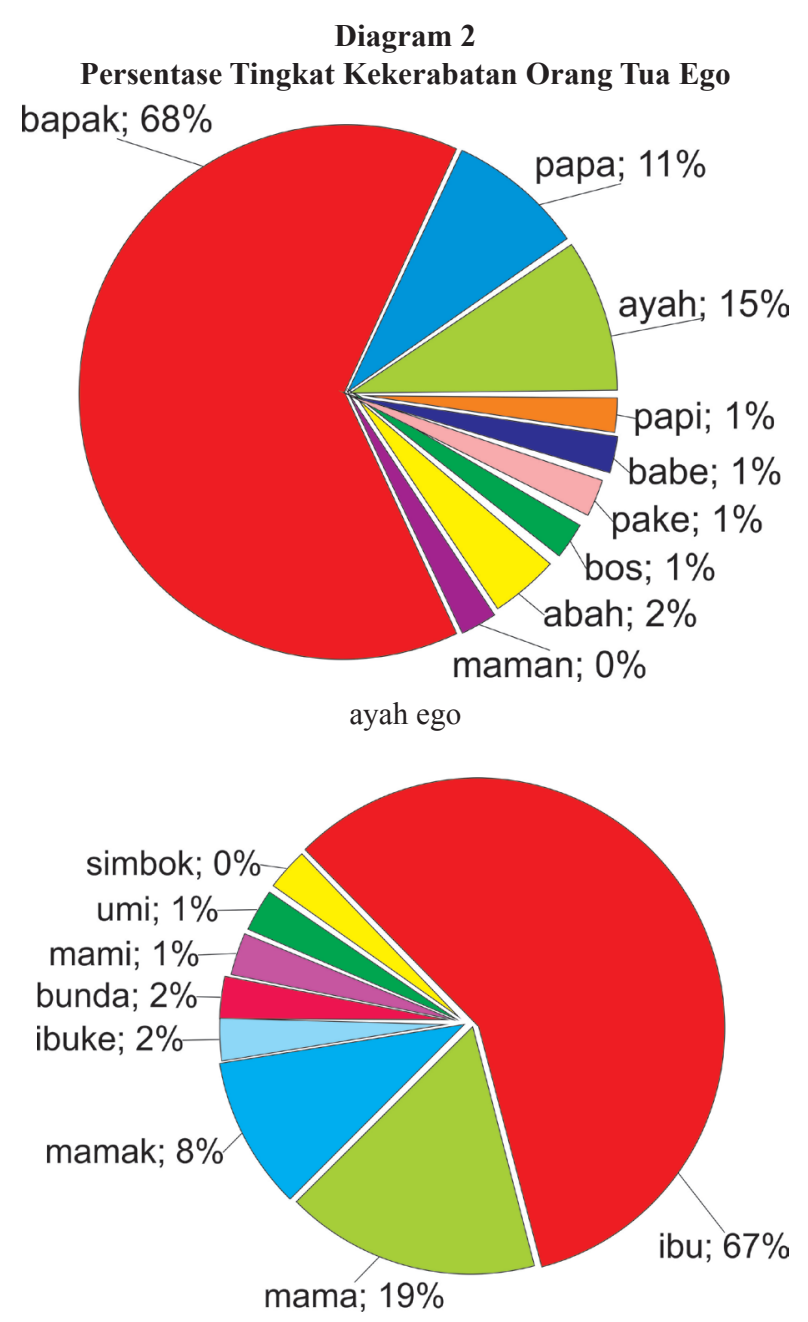

ibu ego

Dari diagram di atas dapat dilihat mayoritas bentuk sapaan yang digunakan adalah bapak sebanyak $68 \%$, papa sebanyak $15 \%$, dan ayah sebanyak $11 \%$. Kemudian, bentuk sapaan lain pun muncul, yakni bos, papi, babe, maman, pake, dan abah. Bentuk-bentuk sapaan tersebut muncul karena setidaknya disebabkan oleh empat hal. Pertama, unsur kedaerahan yang masih kental di dalam lingkungan pembahan, seperti yang terlihat pada sapaan babe. Kedua, tingkat kedekatan antara ayah dan anak yang intim, seperti yang terlihat pada sapaan bos. Ketiga, faktor agama yang kental di dalam lingkungan pembahan yang memunculkan pemakaian sapaan abah. Adapun keempat, status sosial keluarga pembahan punya peran penting di dalam masyarakat.

Sapaan untuk ibu ego pun cukup beragam. Akan tetapi, mayoritas yang digunakan adalah bentuk sapaan $i b u$. Bentuk-bentuk sapaan lain yang memiliki corak kedaerahan yang kental seperti biyung, mamak, atau simbok sangat jarang digunakan. Bentuk sapaan ibu pun di sini bertumpang tindih karena selain merupakan bentuk sapaan yang berasal dari daerah, bentuk sapaan ini telah diserap ke dalam bentuk sapaan bahasa Indonesia sehingga membuat ia berpijak pada dua kedudukan, yakni kedaerahan dan juga nasional.

Selain ayah dan ibu ego, di dalam tingkatan ini juga termuat kakak laki-laki ayah atau ibu dan kakak perempuan ayah atau ibu yang persentase pemakaiannya dapat dilihat pada diagram berikut.
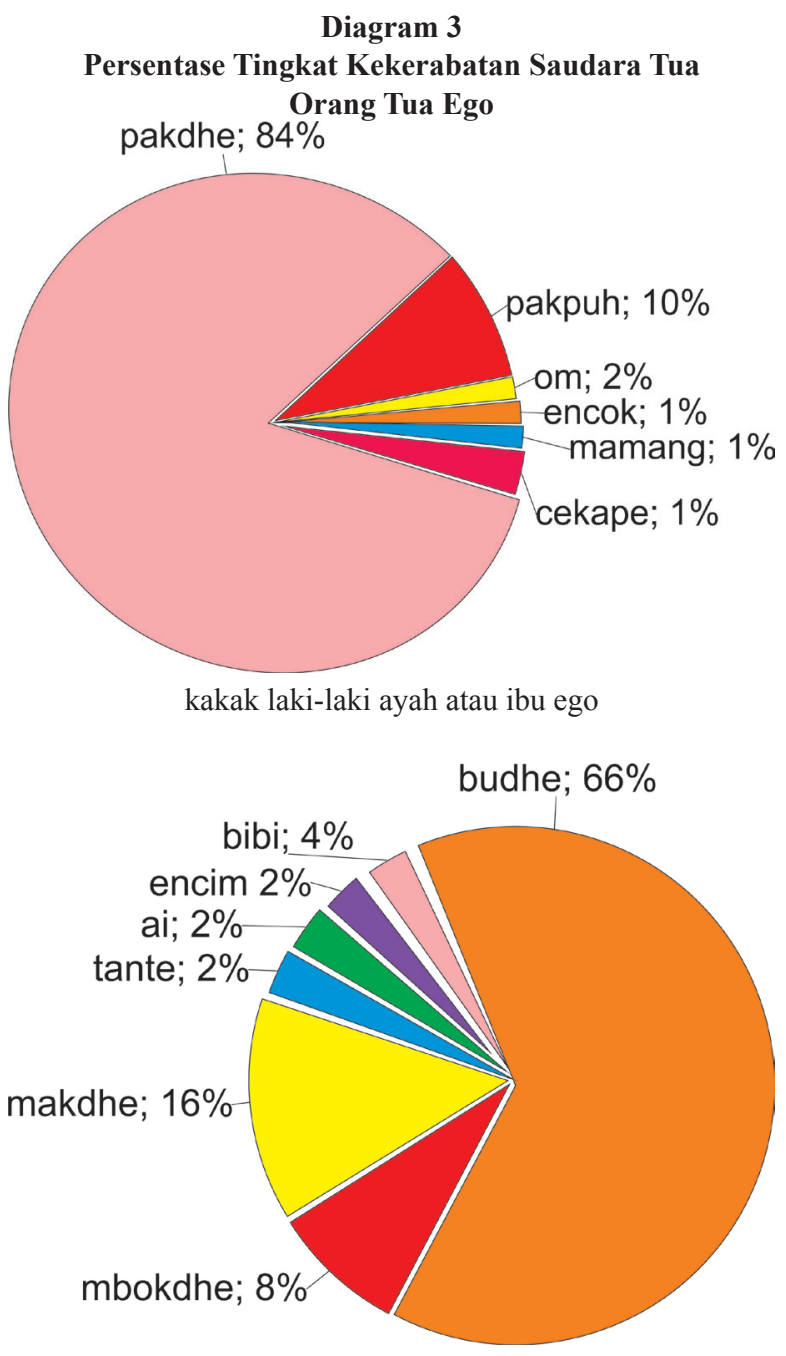

kakak perempuan ayah atau ibu ego

Dari data di atas terlihat bahwa bentuk sapaan terhadap kakak laki-laki ayah atau ibu ego didominasi oleh pakdhe. Sapaan tersebut 
merupakan sapaan hasil kontraksi dari kata bapak dan gedhe. Bentuk sapaan ini memiliki padanan, yakni budhe yang digunakan untuk memanggil kakak perempuan ayah atau ibu ego. Keduanya merupakan sapaan yang berasal dari masyarakat Jawa. Selain itu, bentuk sapaan lain yang digunakan untuk menyapa kakak lakilaki ayah atau ibu adalah pakpuh, om, cekape, mamang, dan encok. Bentuk sapaan pakpuh, cekape, mamang, dan encok merupakan bentuk sapaan yang mengandung unsur kedaerahan yang kental. Kemudian, bentuk sapaan om pun muncul, padahal bentuk sapaan ini merupakan bentuk sapaan yang bersifat nasional.

Tidak jauh berbeda dengan bentuk sapaan terhadap kakak laki-laki, bentuk sapaan terhadap kakak perempuan pun memiliki pola yang hampir sama. Sapaan dengan unsur kedaerahan kental, seperti encim, budhe, mbokdhe muncul di dalam diagram. Selain itu, sapaan yang bersifat nasional, yakni bibi, dan tante, juga muncul.

Kemudian, bentuk sapaan yang ada di dalam tingkatan ini selanjutnya adalah sapaan terhadap adik laki-laki ayah atau ibu ego dan adik perempuan ayah atau ibu ego. Bentuk sapaan tersebut tertuang dalam diagram berikut.

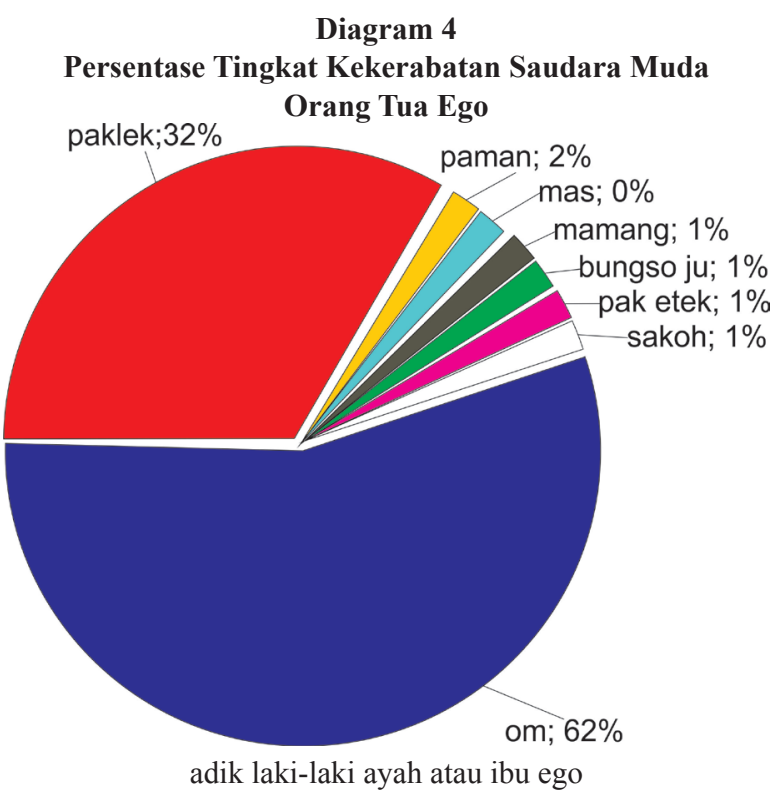

Diagram 4

at Kekerabatan Saudara Muda paman; $2 \%$ mamang; $1 \%$

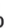

\section{SIMPULAN}

Masyarakat Indonesia memiliki banyak bentuk sapaan sebagaimana yang telah dijabarkan di muka. Berdasarkan pemetaan yang telah dilakukan di muka, bentuk sapaan dapat berupa sapaan berpola utuh, variasi utuh, sebagian, dan tak utuh. Sapaan berpola utuh terbagi atas sapaan, nama, julukan, paraban, dan panggilan. Pola variasi utuh terbagi menjadi pola sapaan ditambah nama, julukan, paraban, atau panggilan. Pola sebagian dibagi menjadi sebutan ditambah klip nama, sapaan ditambah klip nama, julukan, paraban, atau panggilan, dan klip sapaan ditambah nama, julukan, paraban, panggilan, atau dapat pula 
ditambahkan klip nama, klip julukan, klip paraban, atau klip panggilan. Sementara itu, pola tak utuh terbagi menjadi pola merger, kontraksi, dan klip.

Bentuk-bentuk sapaan yang digunakan di Indonesia ada yang menggunakan bahasa Indonesia dan ada pula yang menggunakan bahasa etnis, seperti bahasa Jawa, bahasa Sunda, bahasa Batak, dan lain sebagainya. Selain menggunakan bahasa Indonesia dan bahasa etnis, ada pula sapaan yang berasal dari bahasa Eropa dan bahasa Cina. Adanya kontak dengan beberapa negara dari Eropa seperti Inggris, Belanda, dan Perancis memunculkan bentuk-bentuk sapaan yang telah ditinggalkan dan diwariskan oleh orang-orang terdahulu kepada masyarakat Indonesia. Selanjutnya, bahasa yang digunakan oleh penutur dapat merefleksikan posisi penutur bahasa itu, utamanya terkait dengan siapa penyapanya, orang yang disapa, dan bagaimana relasi antara penyapa dan pesapa. Bentuk-bentuk sapaan yang digunakan oleh penyapa pada gilirannya mampu memperlihatkan urutan usia, kelahiran, gender, tingkat pendidikan, kedekatan relasi, lokasi, profesi, agama, jabatan, tren, lapisan masyarakat, dan pewarisan dalam relasi kekerabatan penyapa.

Adapun terkait dengan dinamika pemakaian bentuk sapaan, dari uraian di atas dapat disimpulkan bahwa pada tingkat kekerabatan ego, terjadi ketumpangtindihan antara bentuk sapaan yang bersifat nasional dan bentuk sapaan yang mengandung unsur kedaerahan. Dalam aktivitas keseharian, bentuk sapaan kedaerahan digunakan untuk menyapa anggota keluarga atau orang tua, tetapi atas pertimbangan tertentu, misalnya tingkat pendidikan, profesi, jabatan, atau pewarisan, sapaan nasional lebih banyak dipakai meski hal itu tidak relevan dengan latar belakang etnis itu. Hal ini merefleksikan fakta kebahasaan yang menyatakan bahwa masyarakat Indonesia, diakui atau tidak, berada dalam dialektika antara lokalitas dan nasionalitas.

\section{DAFTAR PUSTAKA}

Chaer, Abdul. (1995). Pengantar Semantik Bahasa Indonesia. Edisi Revisi. Cet. 2. Jakarta: Rineka Cipta.

Kridalaksana, Harimukti. (1978). Fungsi Bahasa dan Sikap Bahasa. Ende Flores: Nusa Indah. . (1982). Dinamika Tutur Sapa dalam Bahasa Indonesia. Pelangi Bahasa. Harimurti K. dan Anton M. (ed). Jakarta: Bhratara Karya Aksara.

Ngalimun. (2012). Bentuk Sapaan Mesra Antaranggota Keluarga dalam Bahasa Jawa. Jurnal Socioscientia, Vol. 4, No. 2.

Roselani, Ni Gusti Ayu. (1991). Bentuk Sapaan dalam Bahasa Inggris dan Bahasa Indonesia. Jurnal Humaniora, No. 3.

Saefullah, Nurul Hikmayaty. (2010). Keragaman Sapaan dalam Tuturan Seputar Kegiatan Perdagangan di Pasar Banjaran, Kabupaten Bandung. Laporan Penelitian. Bandung, Universitas Padjajaran.

Sari, Nika. (2013). Sistem Kata Sapaan Kekerabatan dalam Bahasa Melayu di Kepenghuluan Bangko Kiri Kecamatan Bangko Pusako Kabupaten Rokan Hilir Provinsi Riau. Jurnal Pendidikan Bahasa dan Sastra Indonesia, Vol. 1 No. 2.

Subiyatningsih. (2008). Kaidah Sapaan Bahasa Madura. Identitas Madura dalam Bahasa dan Sastra. Sidoarjo: Balai Bahasa Surabaya.

Sumampouw, E. (2000). Pola Penyapaan Bahasa Indonesia dalam Interaksi Verbal dengan Latar Multilingual. Kajian Serba Linguistik untuk Anton Moeliono. Jakarta: Pereksa Bahasa.

Sumarsono. (2007). Sosiolinguistik. Yogyakarta: Pustaka Pelajar.

Sugono, Dendy. (2014). Kamus Besar Bahasa Indonesia Pusat Bahasa. Edisi Keempat. Cetakan kedelapan.Jakarta:GramediaPustakaUtama.

Uhlenbeck, E.M. (1982). Ciri-Ciri Sistematis Nama Orang dalam Bahasa Jawa. Kajian Morfologi Bahasa Jawa (Seri ILDEP). Jakarta: Djambatan.

Wasiyati. Kristina. (2008). Referensi, Makna, dan Denotasi. Makalah. Yogyakarta.

Wibowo, Ridha Mashudi. (2001). Nama Diri Etnik Jawa. Jurnal Humaniora, Vol. 13, No. 1. 